\title{
Evaluation of General Characteristics of Renal Cell Carcinoma Patients: A Single Center Experience
}

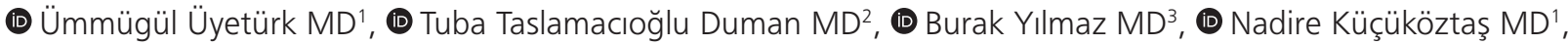 \\ (1) Uğur Üyetürk MD³ \\ 'Abant Izzet Baysal University Faculty of Medicine, Department of Internal Diseases, Division of Medical Oncology, Bolu, Turkey \\ ${ }^{2}$ Abant lzzet Baysal University Faculty of Medicine, Department of Internal Diseases, Bolu, Turkey \\ ${ }^{3}$ Abant lzzet Baysal University Faculty of Medicine, Department of Urology, Bolu, Turkey
}

\begin{abstract}
Objective: Renal cancer (RC) accounts for 3.2\% of all newly diagnosed cancers and approximately $90 \%$ of RC cases are renal cell carcinoma (RCC). Smoking and hypertension are the most important risk factors. The aim of our study was to evaluate the general characteristics of RCC patients in Bolu, Turkey.

Materials and Methods: Patients who visited our medical oncology clinic and were diagnosed with RCC between January $1^{\text {st }}, 2012$ and May $31^{\text {st }}$, 2017 were evaluated retrospectively.

Results: Eighty-one patients were diagnosed with RCC during the study period. The median age of the patients was 62 years (range: $38-87$ years). Fifty-seven (70.4\%) of the patients were male and 24 (29.6\%) were female. Thirty patients (37.1\%) were diagnosed incidentally. Forty-eight (59.3\%) of the patients were smokers. The most common comorbidity was hypertension (58\%). Radical nephrectomy was performed in 59 (72.8\%) of the patients. The most common histological subtype was clear cell carcinoma (72.8\%) and $39(48.1 \%)$ were stage 1 when evaluated according to the stage of RCC. Of the 16 patients with metastatic disease, 11 (13.6\%) received interferon therapy, and 5 patients (6.2\%) refused treatment. After interferon treatment, 7 patients received targeted therapy with sunitinib/pazopanib as second-line treatment, 5 received everolimus as third-line treatment, and 3 received axitinib treatment as fourth-line treatment. Ten patients with bone metastasis underwent palliative radiotherapy. The median follow-up time of the patients was 21 months (0-123 months). Sixty-five patients (80.2\%) survived this period.

Conclusion: Smoking cessation and effective treatment of hypertension, preventable etiological factors of RCC, and incidental diagnosis of early RCC are very important. With early diagnosis, the partial nephrectomy rate might be increased.
\end{abstract}

Keywords: Renal cell carcinoma, etiology, Bolu

\section{Introduction}

Renal cancer (RC) accounts for $3.2 \%$ of all newly diagnosed cancers, $4.1 \%$ in males and $2.5 \%$ in females (1). Approximately $90 \%$ of RCs are renal cell carcinoma (RCC). Based on tumor morphology, immunohistochemistry, cytogenetics, and other molecular studies, the subtypes of RCC are clear cell, papillary, chromophobe, and collecting-duct or Bellini duct tumors. The most common subtype of RCC is clear cell carcinoma, with a rate of approximately $80 \%(2,3,4)$. Cigarette smoking and hypertension are the most important risk factors in the development of $\operatorname{RCC}(5,6)$. Surgery is very important in the treatment of RCC (7). As more patients are diagnosed in the early stages, partial nephrectomy is increasingly used instead of radical nephrectomy for treatment. RCC is a radioresistant tumor; thus, radiotherapy (RT) cannot be used in its treatment. RT can only be performed as palliative treatment in conditions such as brain and bone metastasis $(8,9)$. Systemic treatment is not necessary

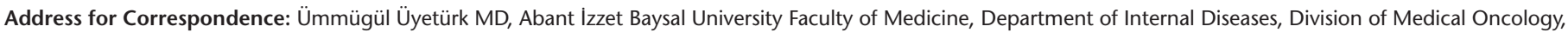
Bolu, Turkey Phone: +90 5326948615 E-mail: ummuguluyeturk@yahoo.com.tr ORCID-ID: orcid.org/0000-0002-6839-2632 Received: 24.11.2017 Accepted: 28.02.2018 
until RCC has reached the metastatic stage. Targeted treatment agents such as sunitinib, pazopanib, sorafenib, bevacizumab, axitinib, everolimus, and temsirolimus are used in the treatment of metastatic disease $(10,11)$. Our study aimed to evaluate the general characteristics of patients with RCC in Bolu, Turkey.

\section{Materials and Methods}

The written and digital records of patients with RCC who were diagnosed between January 1st, 2012 and May 31st, 2017 at the Department of Medical Oncology Outpatient Clinic of Abant Izzet Baysal University Faculty of Medicine were reviewed retrospectively. Age, gender, symptoms at presentation, smoking and alcohol habits, comorbid diseases, family history of cancer, surgical modality, tumor histology, tumor diameter, grade, stage, metastasis location, medical treatment, and final followup dates of the RCC patients were recorded.

\section{Results}

A total of 1870 patients visited our outpatient clinic between January $1^{\text {st }}, 2012$ and May $31^{\text {st }}, 2017,81$ (4.3\%) of whom were diagnosed with RCC. The median age of the patients was 62 years (range: $38-87$ years). Forty-nine $(60.5 \%)$ of the patients were less than 65 years of age and 32 (39.5\%) were over 65 years of age. Fifty-seven (70.4\%) of the patients were male and 24 (29.6\%) were female.

For 30 patients (37.1\%) the renal mass was detected incidentally. Presenting symptoms in the other patients included abdominal pain in 26 patients (32.1\%), hematuria in 7 (8.6\%), abdominal pain and hematuria in $6(7.4 \%)$, weight loss and fatigue in 6 $(7.4 \%)$, and back pain in 6 patients $(7.4 \%)$.

Forty-eight $(59.3 \%)$ of the patients smoked cigarettes and 33 $(40.7 \%)$ did not smoke. Twenty women (83.3\%) and 28 men (49.1\%) smoked. The smoking duration of the patients was 33 pack-years (range: 6-100 pack-years). Seventy-five (92.6\%) of the patients did not use alcohol, while 6 (7.4\%) consumed alcohol.

Forty-three (53.1\%) of the RCC patients had comorbid diseases and 38 (46.9\%) did not. These comorbidities included hypertension in 25 patients $(58.1 \%)$, second primary cancer in $7(16.3 \%)$, diabetes mellitus in $6(13.9 \%)$, and hypertension plus diabetes mellitus in 5 patients $(11.7 \%)$. Seventy patients (86.4\%) had no family history of cancer, while 11 patients (13.6\%) had a family history of cancer. The patients' Eastern Cooperative Oncology Group (ECOG) performance status was evaluated as grade 1 in 70 patients (86.4\%), grade 2 in 8 patients (9.9\%), and grade 3 in 3 patients (3.7\%) (Table 1).

Radical nephrectomy was performed in 59 patients $(72.8 \%)$, partial nephrectomy was performed in 17 patients $(21 \%)$, and 5 patients with metastases did not undergo surgery. Histological subtype was clear cell carcinoma in 59 patients (72.8\%), papillary carcinoma in 12 (14.8\%), chromophobe cell carcinoma in 8 (9.9\%), and collecting duct tumor in 2 patients $(2.5 \%)$. The median tumor diameter was $6 \mathrm{~cm}$ (range: 1.7-18 cm). Tumor diameter was less than $7 \mathrm{~cm}$ in $49(60.5 \%)$ of the patients and 7 $\mathrm{cm}$ or greater in 32 patients (39.5\%). Tumor grade was grade 1 in 12 patients (14.8\%), grade 2 in 27 (33.3\%), grade 3 in 23 (28.4\%), and could not be evaluated in 19 patients (23.5\%). Tumors were stage 1 in 39 patients (48.1\%), stage 2 in 19 patients $(23.5 \%)$, stage 3 in 7 patients (8.6\%), and stage 4 in 16 patients (19.8\%).
Bone metastasis occurred in 9 patients (56.2\%), lung metastasis occurred in 5 (31.2\%), surrenal metastasis occurred in 1 (6.3\%), and multiple metastases such as lung, liver, and bone metastases occurred in 1 patient (6.3\%). Sixty-five patients (80.2\%) had postoperative follow-up. Interferon treatment was given to 11 patients (13.6\%) who had metastasis, and five patients (6.2\%) refused treatment. Seven patients received sunitinib/pazopanib as second-line treatment, 5 received everolimus as third-line treatment, and 3 patients received axinitinib treatment as fourthline treatment. Palliative RT was applied to 10 patients with bone metastasis. No patient had brain metastases. The median followup time of the patients was 21 months (range: 0-123 months). During this time, 65 patients (80.2\%) survived (Table 2).

\begin{tabular}{|c|c|c|c|}
\hline & & $\mathrm{n}$ & $\%$ \\
\hline \multirow[t]{2}{*}{ Gender } & Female & 24 & 29.6 \\
\hline & Male & 57 & 70.4 \\
\hline \multirow[t]{2}{*}{ Cigarette smoking } & Yes & 48 & 59.3 \\
\hline & No & 33 & 40.7 \\
\hline \multirow[t]{2}{*}{ Alcohol consumption } & Yes & 6 & 7.4 \\
\hline & No & 75 & 92.6 \\
\hline \multirow[t]{4}{*}{ Comorbid diseases } & Hypertension & 25 & 58.1 \\
\hline & Second primary cancer & 7 & 16.3 \\
\hline & Diabetes mellitus & 6 & 13.9 \\
\hline & $\begin{array}{l}\text { Diabetes mellitus + } \\
\text { hypertension }\end{array}$ & 5 & 11.7 \\
\hline
\end{tabular}

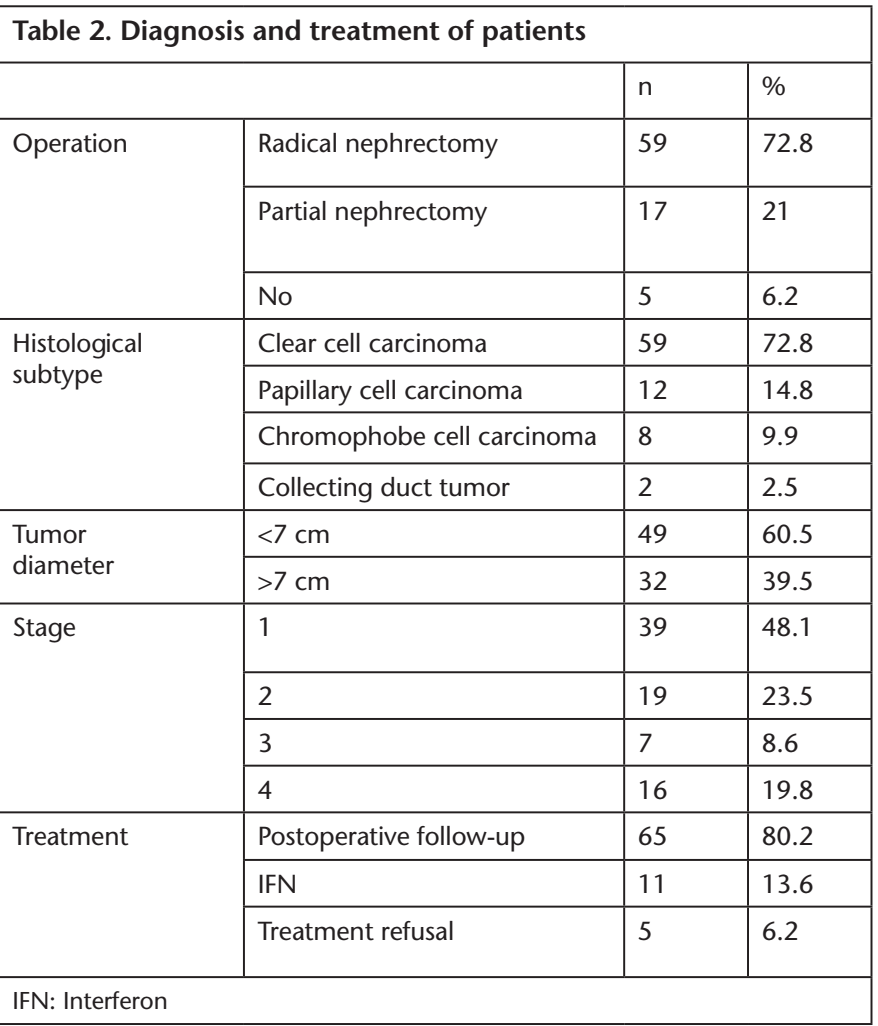




\section{Discussion}

RCC is an age-related disease and is more common in men than in women. According to Surveillance, Epidemiology and End Results Program (SEER) data, the average age at diagnosis is 64 years (12). In a study about RCC conducted by Türk et al. (13), $70 \%$ of the patients were male, and the median age of the patients was 57 years. In another study conducted in patients with RCC, $58.5 \%$ of the patients were male, and the median age was 57 years (14). The proportion of male patients in our study was greater than that of female patients. The median age at diagnosis in our study, 62 years, was higher than the studies cited above and was similar to that in the SEER data.

Cigarette smoking is currently considered the most important risk factor in the development of RCC. According to SEER data, $20-30 \%$ of men and $10-20 \%$ of women diagnosed with RCC are smokers (12). In the VITAL study, there was a relationship between cigarette smoking and RCC formation, but no relationship was found with alcohol consumption (15). In our study, $59.3 \%$ of the patients were cigarette smokers, and only $7.4 \%$ of patients consumed alcohol. Twenty women (83.3\%) and 28 men (49.1\%) were smokers. Unlike the aforementioned studies, the smoking rate in our study was higher in women than in men. This is mainly due to women being more addicted than men to cigarette smoking and the fact that the prevalence of smoking is presently increasing in women but decreasing in men (16).

Hypertension is also important in the etiology of RCC. Some researchers believe that arterial hypertension arises due to vasoactive amines secreted by RCC and causes RCC formation $(15,17,18)$. Chow et al. (19) observed a relationship between elevated blood pressure and risk of RCC development, and they found that the risk might be decreased with time if blood pressure was well controlled. In another study, it was found that the risk of RCC development was over 2.4 times greater in patients with high blood pressure (20). In our study, hypertension was noted in half of the patients. Effective treatment of hypertension, which plays a significant role in RCC etiology, is very important.

Clear cell carcinoma (80-90\%), papillary carcinoma (10-15\%), and chromophobe carcinoma (4-5\%) are the most common histological subtypes of RCC (21). In a study in which Kuş et al. (22) assessed the histopathological features of RCC patients, the most common histological subtype was clear cell carcinoma, accounting for $88.6 \%$ of cases. In another study concerning histological subtype, clear cell carcinoma was the most common subtype with a rate of $85 \%$ (13). Consistent with these studies, we also found that the most common histological subtype among our patients was clear cell carcinoma.

Approximately $65 \%$ of patients with RCC are asymptomatic in terms of clinical and laboratory factors and are usually diagnosed incidentally $(23,24)$. In particular, the symptom-based diagnosis rate of RCC patients has been reduced because of easier access and more frequent use of abdominal ultrasound and computed tomography. The proportion of incidentally diagnosed patients has increased 3 fold within 20 years $(25,26)$. In our study, the incidental diagnosis rate of RCC was greater than diagnosis by other means.

In terms of tumor stage, a study evaluating 198 patients with $\mathrm{RCC}$ reported higher proportions of stage 1 and stage 2 tumors than metastatic disease (14). In another study of the clinical and histopathological features of 230 patients with RCC, the number of stage 1 patients was 110 (49\%), a high rate (13). In keeping with the increase in the use of radiological diagnostic tests, the proportion of stage 1 patients in our study was $48.1 \%$, similar to that in recent studies.

Surgery for localized RCC disease is usually curative treatment. Local ablation, partial nephrectomy, or total nephrectomy may be performed, depending on tumor size (27). Similar local recurrence rates have been reported with partial nephrectomy and local ablation therapy. None of the patients in our study underwent local ablative treatment (28). In another study performed in the last 15 years, total nephrectomy was still performed, although the partial nephrectomy rate in patients with a tumor diameter less than $2 \mathrm{~cm}$ increased from $15.3 \%$ to $61.1 \%$. If the tumor diameter was $2-2.9 \mathrm{~cm}$, the rate increased from $11.0 \%$ to $44.2 \%$; if the tumor diameter was $3-3.9 \mathrm{~cm}$, the rate was increased from $7.2 \%$ to $31.1 \%$ (29). In our study, the total nephrectomy rate was higher than the partial nephrectomy rate.

RT is administered as palliative treatment for bone and brain metastases. In fact, RCC is a radioresistant tumor $(30,31,32)$. No brain metastatic patients were found in our study. Ten patients with bone metastasis had palliative RT treatment.

Targeted therapies are used in metastatic RCC patients. In a recent study comparing the molecular targeted agent sunitinib to interferon, sunitinib yielded higher disease-free survival and response rates. Additionally, in another recent study, pazopanib and sunitinib showed similar efficacy in metastatic disease $(33,34)$. Despite these findings, due to the policies of the Turkish Ministry of Health, interferon is still used as first-line therapy for metastatic RCC. In our study, interferon therapy was started in 11 of the metastatic patients, and 7 patients who showed progression with interferon treatment were treated with targeted agents. Five patients refused treatment.

In our study, the median follow-up time was 21 months, and 65 patients survived. In another study, the median follow-up time was 33 months and 57 patients survived (35). In yet another study, 61 patients survived and the median follow-up time was 46 months (36).

\section{Study Limitations}

Limitations of this study include its retrospective design and the small number of patients.

\section{Conclusion}

Reduction in cigarette smoking and control of risk factors such as hypertension are important in the prevention of RCC. Renal cell cancer should be diagnosed early because partial nephrectomy can be performed instead of total nephrectomy, especially with small-diameter tumors.

\section{Ethics}

Ethics Committee Approval: This study was a retrospective medical record review. For this reason, ethical approval was not received.

Informed Consent: Retrospective study. 
Peer-review: Externally peer-reviewed.

\section{Authorship Contributions}

Surgical and Medical Practices: Ü.Ü., T.T.D., B.Y., N.K., U.Ü., Concept: Ü.Ü., Design: Ü.Ü., T.T.D., Data Collection or Processing: T.T.D., B.Y., N.K., Analysis or Interpretation: Ü.Ü., U.Ü., Literature Search: Ü.Ü., T.T.D., U.Ü., Writing: Ü.Ü.

Conflict of Interest: No conflict of interest was declared by the authors.

Financial Disclosure: The authors declared that this study received no financial support.

\section{References}

1. Miller KD, Siegel RL, Lin CC, et al. Cancer treatment and survivorship statistics, 2016. CA Cancer J Clin 2016;66:271-289.

2. Leibovich $B C$, Lohse $C M$, Crispen $\mathrm{PL}$, et al. Histological subtype is an independent predictor of outcome for patients with renal cell carcinoma. J Urol 2010;183:1309-1315.

3. Moch $\mathrm{H}$, Montironi R, Lopez-Beltran A, et al. Oncotargets in different renal cancer subtypes. Curr Drug Targets 2015;16:125-135.

4. Ellati RT, Abukhiran I, Alqasem K, et al. Clinicopathologic Features of Translocation Renal Cell Carcinoma. Clin Genitourin Cancer 2017;15:112-116.

5. Kabaria R, Klaassen Z, Terris MK. Renal cell carcinoma: links and risks. Int J Nephrol Renovasc Dis 2016;9:45-52.

6. Ljungberg B, Campbell SC, Choi HY, et al. The epidemiology of renal cell carcinoma. Eur Urol 2011;60:615-621.

7. White V, Marco DJT, Bolton D, et al. Trends in the surgical management of stage 1 renal cell carcinoma: findings from a population-based study. BJU Int 2017;120:6-14.

8. De Meerleer G, Khoo V, Escudier B, et al. Radiotherapy for renal-cell carcinoma. Lancet Oncol 2014;15:170-177.

9. Kothari G, Foroudi F, Gill $S$, et al. Outcomes of stereotactic radiotherapy for cranial and extracranial metastatic renal cell carcinoma: a systematic review. Acta Oncol 2015;54:148-157.

10. Buti $S$, Bersanelli $M$, Sikokis $A$, et al. Chemotherapy in metastatic renal cell carcinoma today? A systematic review. Anticancer Drugs 2013;24:535-554.

11. Daste A, Grellety T, Gross-Goupil M, Ravaud A. Protein kinase inhibitors in renal cell carcinoma. Expert Opin Pharmacother 2014;15:337-351.

12. Altekruse SF, Dickie L, Wu XC, et al. Clinical and prognostic factors for renal parenchymal, pelvis, and ureter cancers in SEER registries: collaborative stage data collection system, version 2. Cancer 2014;120(Suppl 23):3826-3835.

13. Türk $A$, Aslan $H$, Balaban $M$, ve ark. Böbreğin Renal Hücreli Kanserlerinde Klinik ve Histopatolojik Özellikler. J Kartal TR 2014;25:124-126.

14. Atan A, Tuncel A, Aslan Y, ve ark. Böbrek Hücreli Kanser Hastalarında Tümör Sayısı Ve Adrenal Bez Tutulumunu Belirlemede Bilgisayarlı Tomografi Güvenilir Midir? Çok Merkezli Bir Çalışma. Türk Üroloji Dergisi 2005;31:329-334.

15. Macleod LC, Hotaling JM, Wright JL, et al. Risk factors for renal cell carcinoma in the VITAL study. J Urol 2013;190:1657-1661.
16. Visal Buturak Ş, Günal N, Özçiçek G, ve ark. Sigara bırakma polikliniğine başvuran hastaların sosyodemografik özellikleri ve sigara bağımlılık şiddetleri. Turk J Clin Lab 2016;7:72-76.

17. Stojanovic M, Goldner B, Ivkovic D. Renal cell carcinoma and arterial hypertension. Clin Exp Nephrol 2009;13:295-299.

18. Chow WH, Dong LM, Devesa SS. Epidemiology and risk factors for kidney cancer. Nat Rev Urol 2010;7:245-257.

19. Chow WH, Gridley G, Fraumeni JF Jr, Jarvholm B. Obesity, hypertension, and the risk of kidney cancer in men. $N$ Engl J Med 2000;343:1305-1311.

20. Weikert S, Boeing $\mathrm{H}$, Pischon $\mathrm{T}$, et al. Blood pressure and risk of renal cell carcinoma in the European prospective investigation into cancer and nutrition. Am J Epidemiol 2008;167:438-446.

21. Jiang HM, Wei JH, Zhang ZL, et al. Does chromophobe renal cell carcinoma have better survival than clear cell renal cell carcinoma? A clinical-based cohort study and meta-analysis. Int Urol Nephrol 2016;48:191-199.

22. Kuş E, Yıldız K, Dillioğlugil Ö. Böbrek Hücreli Karsinomda Fuhrman Çekirdek Derecesi ve Evrenin Sağkalımla İlişkisi. Türk Patoloji Dergisi 2009;25:71-77.

23. Rabjerg $M$, Mikkelsen $M N$, Walter S, Marcussen N. Incidental renal neoplasms: is there a need for routine screening? A Danish singlecenter epidemiological study. APMIS 2014;122:708-714.

24. Bayraktar Z, Atun I, Dama N. Rastlantısal böbrek hücreli karsinomların tespitinde ultrasonografinin önemi. Turkish Journal of Urology 2009;35:281-285.

25. Palsdottir HB, Hardarson $S$, Petursdottir $\mathrm{V}$, et al. Incidental detection of renal cell carcinoma is an independent prognostic marker: results of a long-term, whole population study. J Urol 2012;187:48-53.

26. Tsui KH, Shvarts O, Smith RB, et al. Renal cell carcinoma: prognostic significance of incidentally detected tumors. JUrol 2000;163:426-430.

27. Tan HJ. Survival benefit of partial nephrectomy: Reconciling experimental and observational data. Urol Oncol 2015;33:505.

28. Thompson RH, Atwell T, Schmit G, et al. Comparison of partial nephrectomy and percutaneous ablation for $\mathrm{CT} 1$ renal masses. Eur Urol 2015;67:252-259.

29. Cooperberg MR, Mallin K, Kane CJ, Carroll PR. Treatment trends for stage I renal cell carcinoma. J Urol 2011;186:394-399.

30. De Meerleer G, Khoo V, Escudier B, et al. Radiotherapy for renal-cell carcinoma. Lancet Oncol 2014;15:170-177.

31. Lwu S, Goetz P, Monsalves E, et al. Stereotactic radiosurgery for the treatment of melanoma and renal cell carcinoma brain metastases. Oncol Rep 2013;29:407-412.

32. Dabestani S, Marconi L, Hofmann F, et al. Local treatments for metastases of renal cell carcinoma: a systematic review. Lancet Oncol 2014;15:549-561.

33. Motzer RJ, Hutson TE, Tomczak $P$, et al. Sunitinib versus interferon alfa in metastatic renal-cell carcinoma. N Engl J Med 2007;356:115-124.

34. Motzer RJ, Hutson TE, Cella D, et al. Pazopanib versus sunitinib in metastatic renal-cell carcinoma. N Engl J Med 2013;369:722-731.

35. Motzer RJ, Mazumdar M, Bacik J, et al. Survival and prognostic stratification of 670 patients with advanced renal cell carcinoma. I Clin Oncol 1999;1 7:2530-2540.

36. Motzer RJ, Bacik J, Murphy BA, et al. Interferon-alfa as acomperative treatment for clinical trials of new therapies against advanced renal cell carcinoma J Clin Oncol 2002;20:289-296. 